\title{
ANNOUNCEMENTS
}

6TH INTERNATIONAL MYCOLOGICAL CONFERENCE, 23-28 August 1998

Jerusalem, Israel

M. Galan, PO Box 50006, Tel Aviv 61500, Israel.

Fax: 9723517564

4TH INTERNATIONAL CONFERENCE OF THE HOSPITAL INFECTION SOCIETY, 13-17 September 1998

Edinburgh, Scotland

Index Communications Meetings Services, Crown House, 28 Winchester Road, Romsey, Hampshire SO51 8AA, UK. Tel: 44 (0)1794 511331; Fax: 44 (0)1794 511455; e-mail: his.icms@dial.pipex.com; WWW: http://www.hubk.co.uk/wbs/jhi/

38TH INTERSCIENCE CONFERENCE ON ANTIMICROBIAL AGENTS AND CHEMOTHERAPY, 24-27 September 1998

San Diego, California, USA

ASM Meetings Department, 1325 Massachusetts Avenue NW, Washington DC 20005, USA. Tel: 1 202942 9297; Fax: 12029429267

2ND WORLD CONGRESS ON ANAEROBIC BACTERIA AND INFECTIONS, 3-6 October 1998

Nice, France

International Society for Anerobic Bacteria, 181 Longwood Avenue, Boston MA 02115, USA. Tel: 1617738 9951; Fax: 16177311541
4TH INTERNATIONAL CONGRESS ON DRUG THERAPY IN HIV INFECTION, 8-12 November 1998

Glasgow, Scotland

Gardiner Caldwell Communications, Victoria Mill, Windmill Street, Cheshire SK11 7PT, UK. Tel: 44 (0)1625 664000; Fax: 44 (0)1625 6641145; WWW: http://www.pslgroup.com/ dg/299fa.htm

2ND INTERNATIONAL MEETING ON THE THERAPY OF INFECTIONS, 18-21 November 1998

Florence, Italy

American Express Services Europe Ltd, Via Dante Alighieri 22R, 50122 Florence, Italy. Tel: 3955509 8231; Fax: 39 555098220; e-mail: amexfirenze@ cdc.it

9TH EUROPEAN CONGRESS ON CLINICAL MICROBIOLOGY AND INFECTIOUS DISEASES, 21-24 March 1999

Berlin, Germany

9th ECCMID '99, CPO HANSER SERVICE, Schaumburgallee 12, D-14052 Berlin, Germany. Tel: 4930300 6990; Fax: 4930305 7391; e-mail: cpo@eccmid-berlin.de

\section{Pathological Society of Great Britain and Ireland Fellowships}

The Pathological Society of Great Britain and Ireland sponsors a small number of Fellowships for members of the medical and allied professions, resident in the UK, to enable them to travel to other institutions to learn new techniques of value in their clinical study and/or laboratory research. They are available for a period of study of up to 12 months and preference will be given to those requiring additional funds to augment their existing salary. A maximum sum of $£ 5000$ will be allocated to any one person but applications for smaller sums are welcomed. Further details and application forms from: Mrs J. Edwards, Administrator, Pathological Society of Great Britain and Ireland, 2 Carlton House Terrace, London SW1Y 5AF. Closing dates for applications: 1st March and 1st October. 